\title{
VOLTAIRE AND THE NECESSITY OF MODERN HISTORY
}

\section{PIERRE FORCE}

Department of French, Columbia University

E-mail: pf3@columbia.edu

This article revisits what has often been called the "naive presentism" of Voltaire's historical work. It looks at the methodological and philosophical reasons for Voltaire's deliberate focus on modern history as opposed to ancient history, his refusal to "make allowances for time" in judging the past, and his extreme selectiveness in determining the relevance of past events to world history. Voltaire's historical practice is put in the context of the quarrel of the ancients and the moderns, and considered in a tradition of universal history going back to Bossuet and leading up to nineteenth-century German historicism. Paradoxically, Voltaire is a major figure in the history of historiography not in spite of his presentism (as Ernst Cassirer and Peter Gay have argued), but because of it.

A significant proportion of Voltaire's enormous output is historical in nature: a life of Charles XII of Sweden (1731), ${ }^{1}$ a cultural history of France under Louis XIV (1751), ${ }^{2}$ a history of the War of $1741(1755),{ }^{3}$ a history of Russia under Peter the Great (1760), ${ }^{4}$ a précis of the age of Louis XV (1768), ${ }^{5}$ a history of the Parliament of Paris (1769), ${ }^{6}$ and a very ambitious Essay on the Manners and Spirit of Nations $(1756),{ }^{7}$ which was a secular continuation of Bossuet's Discourse on Universal History. Yet Voltaire's status as a historian is an ambiguous one. The Essay on

\footnotetext{
Voltaire, Histoire de Charles XII, in idem, Oeuvres historiques, ed. René Pomeau (Paris: Gallimard, 1957), 51-275.

2 Voltaire, Le Siècle de Louis XIV, in idem, Oeuvres historiques, 603-1274.

3 Voltaire, Histoire de la guerre de 1741, in idem, Oeuvres historiques, 1575-1656.

4 Voltaire, Histoire de l'Empire de Russie sous Pierre le Grand, in idem, Oeuvres historiques, 337-602.

5 Voltaire, Précis du Siècle de Louis XV, in idem, Oeuvres historiques, 1297-1571.

$6 \quad$ Voltaire, Histoire du Parlement de Paris, ed. John Renwick, in idem, The Complete Works of Voltaire, vol. 68 (Oxford: Voltaire Foundation, 2005).

7 Voltaire, Essai sur les moeurs et l'esprit des nations, edited by René Pomeau, 2 vols. (Paris: Garnier, 1963).
} 
Manners was greatly influential in eighteenth-century Europe, but academic historians like those of the Göttingen School were deeply suspicious of the kind of philosophical history that Voltaire practiced and advocated. In a brief and scathing review of the German translation of the second part of his history of the Russian empire, Schlözer accused Voltaire of errors, lies, faulty reasoning, and gross ignorance. ${ }^{8}$ Gatterer ranted against the "pretentious little Humes or Robertsons, the little German Voltaires," and vowed "to hunt down these insects without mercy, wherever they may be," because "they can be dangerous, like all insects." 9 When such distinguished representatives of German academic history as Dilthey and Meinecke looked back at the history of the discipline, their view of Voltaire was much more generous than that expressed by their eighteenth-century predecessors, Gatterer and Schlözer. In 1901 Dilthey wrote that Voltaire was "the first to attempt an account of the new universal history of human culture," and that "the effect produced by applying the new ideas to historical facts was extraordinary." ${ }^{11}$ In 1936 Meinecke argued that

the first and crowning achievement of the Enlightenment in the historical sphere is to be seen in the work of Voltaire. In many respects, it is true, the historical achievements of Hume, Robertson and Gibbon may be ranked higher than Voltaire's; but no one occupies such a broad and obvious and above all effective position within the whole development of historical thought. ${ }^{12}$

8 August Ludwig Schlözer, in Allgemeine deutsche Bibliotek, vol. 10 (1769), 254-5. See Gabriela Lehmann-Carli, "La Critique par Schlözer de l'ouvrage de Voltaire Histoire de l'empire de Russie sous Pierre le Grand," in Katia Dmitrieva and Michel Espagne, eds., Philologiques IV. Transferts culturels triangulaires France-Allemagne-Russie (Paris: Maison des sciences de l'homme, 1996), 63-72. On the Göttingen school see Peter Hanns Reill, The German Enlightenment and the Rise of Historicism (Berkeley: University of California Press, 1975); and Michael C. Carhart, The Science of Culture in Enlightenment Germany (Cambridge, MA: Harvard University Press, 2007).

9 Johann Christoph Gatterer, in Historisches Journal, von Mitgliedern der königlichen historischen Instituts zu Göttingen, vol. 1 (1773), 2. Unless otherwise specified, translations are mine.

10 Wilhelm Dilthey, "The Eighteenth Century and the Historical World," in idem, Hermeneutics and the Study of History (Princeton: Princeton University Press, 1996), 348 ("Das achtzehnte Jahrhundert und die geschichtliche Welt," Deutsche Rundschau 108 (1901), 241-62, 350-80). When I quote another edition than the original, I give the date of the original between parentheses.

$11 \quad$ Ibid.

12 Friedrich Meinecke, Historism: The Rise of a New Historical Outlook (New York: Herder and Herder, 1972), 54 (Die Enstehung des Historismus, 2 vols. (Berlin: R. Oldenbourg, 1936)). 
Meinecke added that "never before . . . had there been such a deliberate and determined effort to distinguish between the valuable and the valueless in the broad mass of historical events." 13

Since his elevation to the status of founding father of modern historical thinking by Dilthey and Meinecke, Voltaire has had mixed fortunes in scholarly accounts. In her chapter on Voltaire, Karen O’Brien begins by stating that "Voltaire's histories have not recovered today from the low reputation to which they sank after the French Revolution." 14 She proceeds to give a nuanced account of Voltaire's contributions to cosmopolitan history in the eighteenth century, "without wishing to make excessive claims for their merit and influence." ${ }^{15}$ In his multivolume study of Gibbon, John Pocock calls Voltaire "the exasperating predecessor," 16 whose oeuvre was of "vast importance to Gibbon, whenever and by what stages he carried it out." 17 Voltaire taught Gibbon how "the Enlightened narrative" could be constructed "by means of a history of manners at once erudite and philosophical."18 However, because "Voltaire would not share his sources or his methods with others, it became doubtful whether he respected their judgment or even his own." ${ }^{19}$ Since the 1958 studies by Brumfitt ${ }^{20}$ and Diaz, ${ }^{21}$ only two monographs have appeared on Voltaire and history. John Leigh's book explicitly situates itself as a continuation of Brumfitt's work and studies the historical aspects of those works by Voltaire that are not usually categorized as historical. ${ }^{22}$ For her part, Síofra Pierse notes that "Voltaire's historiography has not yet been deciphered in a coherent fashion." ${ }^{23}$ However, she deliberately stays away from the question of the innovativeness or coherence of Voltaire's historical method. Overall, in the huge Voltaire bibliography, the percentage of studies dedicated to Voltaire the historian is very small, especially (and surprisingly) in the French language. As John Leigh puts it, tongue-in-cheek, "the paucity of

13 Ibid.

14 Karen O'Brien, Narratives of Enlightenment: Cosmopolitan History from Voltaire to Gibbon (Cambridge: Cambridge University Press, 1997), 21.

15 Ibid.

16 J. G. A. Pocock, Barbarism and Religion, vol. 2 (Cambridge: Cambridge University Press, 1999), 153 .

17 Ibid., 156.

18 Ibid.

19 Ibid., 157.

20 J. H. Brumfitt, Voltaire Historian (Oxford: Oxford University Press, 1970; first published 1958).

21 Furio Diaz, Voltaire Storico (Turin: Einaudi, 1958).

22 John Leigh, Voltaire: A Sense of History, SVEC series (Oxford: Voltaire Foundation, 2004).

23 Síofra Pierse, Voltaire Historiographer: Narrative Paradigms, SVEC series, 6 (Oxford: Voltaire Foundation, 2008). 
French studies devoted to Voltaire's histories might be explained by the prosperity of French historiography: Voltaire's place in an ever progressive, sophisticated tradition is possibly thought to be superfluous, incongruous, perhaps even mildly embarrassing." 24 There is, however, at least one powerful counterexample to this characterization. When he edited his "New History" manifesto in 1978 (with Roger Chartier and Jacques Revel) Jacques Le Goff quoted extensively from the "New Considerations on History?", and he claimed Voltaire as one of the "fathers" of histoire nouvelle (the oldest in a group of ancestors that also included Chateaubriand, Guizot, Michelet, and Simiand). ${ }^{25}$

Whatever importance one grants him in the history of historical thought, all studies of Voltaire betray the same unease, which probably stems from the fact that Voltaire did what every history student is taught to avoid: he was an unabashed presentist, frequently judgmental and moralizing. On the other hand, whatever can be redeemed in his historical method (distinguishing fact from fiction, criticizing sources) is so obvious and unobjectionable that it seems hardly worth mentioning. This unease can be seen in standard accounts of the Enlightenment, which include various attempts to exonerate Voltaire from the Romantic accusation that he had no sense of history. Cassirer notices that Voltaire falls prey to "naïve teleology," ${ }^{26}$ yet argues that the flaws in his approach "are far less weaknesses of his system than those arising from his personality and temperament." 27 Peter Gay (who studies Voltaire along with Hume, Robertson, and Gibbon without making distinctions between these four historians) concedes that the view of history of the philosophes "has come to seem naïve." ${ }^{28}$ As a result, "the historical masterpieces of Voltaire and the others have faded into museum pieces." 29 On the other hand, Peter Gay sees the philosophes' critique of Christian history writing and their secularization of the art of history as a major contribution. (Interestingly, in Jonathan Israel's recent studies, ${ }^{30}$ there is very little about the Enlightenment historians.)

I would like to argue that these standard characterizations tend to obscure Voltaire's role in the history of historiography: they treat Voltaire's presentism as a

24 Leigh, Voltaire: A Sense of History, xvi.

25 Jacques Le Goff, "L'Histoire nouvelle," in Jacques Le Goff, Roger Chartier, and Jacques Revel, eds., La nouvelle Histoire (Paris: Encyclopédies du savoir moderne, 1978), 222.

26 Ernst Cassirer, The Philosophy of the Enlightenment, trans. Fritz C. A. Koehl and James P. Pettegrove (Princeton, Princeton University Press, 1951), 221.

27 Ibid.

28 Peter Gay, The Enlightenment: An Interpretation. The Science of Freedom (New York: W. W. Norton, 1969), 386.

29 Ibid.

30 Jonathan I. Israel, Radical Enlightenment (Oxford: Oxford University Press, 2001); idem, Enlightenment Contested (Oxford: Oxford University Press, 2006). 
methodological shortcoming, and they endorse the rest of his method uncritically. They do not ask if Voltaire's approach to history writing might have had a coherence, and what this coherence might have been. As Suzanne Gearhart puts it, "if Voltaire poses a difficulty to the modern reader, it is often not because his ideas seem antiquated and bizarre, but because they seem so self-evident as to be banal." ${ }^{11}$ In that sense, retrieving the coherence of Voltaire's history involves a dual task: on the one hand, what seems odd and antiquated must be contextualized; on the other, what seems obvious and banal must be questioned. Voltaire's presentism is especially interesting in this perspective: on the one hand, it requires contextualization because no historian today would dare to write the kind of present-centered history that Voltaire wrote; on the other, there is something eerily familiar in Voltaire's emphasis on the present, and if we have to remind ourselves to avoid using absolute moral categories in judging the past, it may be precisely because our first inclination is to do so. Jonathan Israel's enthusiastic and provocative embrace of this inclination in Enlightenment Contested is methodologically correct because it takes place only in the postscript, but it gives voice to an impulse that is as widely shared as it is repressed. ${ }^{32}$

Why focus on Voltaire instead of other canonical Enlightenment historians? The first reason is that Voltaire's historical work pre-dates the work of Hume, Robertson, and Gibbon. The Age of Louis XIV was ready in draft form in the late 1730s, and the first draft of the Essay on Manners was completed in the mid-1740s. Secondly, the histories of Hume, Robertson, and Gibbon were, in different ways, continuations or revisions of Voltaire's project. Thirdly, Voltaire was the most programmatic of all Enlightenment historians: his historical work was unusually self-reflexive, and he wrote extensively on the art of writing history. The last, and most important reason, is that Voltaire provides the clearest case of a historian inhabiting two worlds: our own, and what George Nadel called "the philosophy of history before historicism." 33 Voltaire did see himself as belonging to the humanist tradition of artes historicae (recently reappraised by Anthony Grafton ${ }^{34}$ ) and whatever revolutions he accomplished in historical thinking were carried out in the language of humanism. Nadel rightly notes that what Cassirer and Meinecke read as revolutionary statements in Enlightenment historians were

31 Suzanne Gearhart, The Open Boundary of History and Fiction: A Critical Approach to the French Enlightenment (Princeton: Princeton University Press, 1984), 38, n. 11.

32 Israel, Enlightenment Contested, 863-71. For a critique of the presentism that permeates Israel's work see Anthony La Vopa, "A New Intellectual History? Jonathan Israel's Enlightenment," Historical Journal 52 (2009), 717-738.

33 George H. Nadel, "Philosophy of History before Historicism," History and Theory $3 / 3$ (1964), 291-315.

34 Anthony Grafton, What Was History? The Art of History in Early Modern Europe (Cambridge: Cambridge University Press, 2007). 
in fact "merely paraphrases or quotations from the classics, drearily familiar to any educated person living between the Renaissance and the nineteenth century." 35 On the other hand, as Grafton points out, early eighteenth-century historians like Le Clerc and Perizonius shared the language and methods of their humanist predecessors, but they lived in a new and very different cultural universe. ${ }^{36}$ By focusing on Voltaire's connection with the humanist tradition, I hope to get a better grasp of Voltaire's innovativeness, bearing in mind that the new and the old may not be where they are thought to be. What seems new may be a repetition of the old, and what seems a repetition of the old may be an occurrence of the new.

What was new in Voltaire's way of doing history? An essential part of the answer, I shall argue, is Voltaire's focus on the present. Remarkably, this aspect has been given little consideration, perhaps because it seemed too obvious. Brumfitt notes in passing that Voltaire showed a preference for modern history, but he does not ask what the philosophical reasons for this preference might be, except for a brief mention of historical Pyrrhonism ${ }^{37}$ and the possible influence of Bolingbroke. ${ }^{38}$ Most other historians and critics simply do not mention it. I contend, on the contrary, that understanding Voltaire's preference for modern history is the key to understanding what was new about his approach. Voltaire developed a new conception of the relationship between the past and the present, which can be seen in: (1) a deliberate focus on modern history as opposed to ancient history, (2) an adamant refusal to "make allowances for time" in judging the past, and

(3) extreme selectiveness in determining the relevance of past events to universal history.

\section{ALL HISTORY IS RECENT}

In his Advice to a Journalist (1737), Voltaire wrote, "As to the young, do instill in them a taste for the history of recent times, which to us is a matter of necessity, rather than ancient history, which is only a matter of curiosity." 39 In making such a statement, Voltaire was taking a polemical stance against the academic history of his time, best represented by Charles Rollin (1661-1741), rector of the University of Paris from 1694 to 1712, and author of an Ancient History of the Egyptians, Carthaginians, Assyrians, Babylonians, Medes and Persians, Macedonians, and

\footnotetext{
Nadel, "Philosophy of History before Historicism," 292.

Grafton, What Was History? 254.

Brumfitt, Voltaire Historian, 84.

Ibid., 44 .

Voltaire, Conseils à un journaliste (May 10, 1737), in Oeuvres complètes de Voltaire, ed. Louis Moland, 50 vols. (Paris: Garnier, 1877-85), 22: 244.
} 
Grecians that was widely re-published and translated throughout Europe until the mid-nineteenth century..$^{40}$ In the preface to his Method of Teaching and Studying the Belles Lettres, Rollin, after quoting the inevitable passage from Cicero on the uses of history ("It is not without reason that History has been ever looked upon as the light of ages"), ${ }^{41}$ had argued that the fundamental purpose of history was to take us beyond the confines of our own time:

Confined without it to the bounds of the age and country wherein we live, and shut up in the narrow circle of such branches of knowledge as are peculiar to us, and within the limits of our own private reflections, we remain ever in a kind of infancy, which leaves us strangers to the rest of the world, and profoundly ignorant of all that has gone before us, or even now surrounds us. ${ }^{42}$

Later in the preface, Rollin adds, "I make no mention here of the history of France, as it is but natural that ancient history should precede the modern." 43 He goes on to say that he is ashamed that the history of France has been neglected, and he regrets that "we have no time to teach the schoolboys the history of France." 44 It is clear, however, that curricular constraints are not the fundamental reason. Rollin's history is what Thomas Pavel, in a slightly different context, has called "an art of distancing." 45 Since the purpose of history is to take us beyond the confines of our own time, the further we go into the past, the more effective the distancing is. In that sense, history is, fundamentally, ancient history. Voltaire took the opposite stance: modern history had to be preferred to ancient history for both methodological and philosophical reasons.

Methodologically, knowledge of the recent past was more certain and easier to acquire than knowledge of the distant past: "Modern history has the advantage of being more certain, because of the very fact that it is modern." ${ }^{6}$ In that sense, the focus on modern history was simply a consequence of the shift to

40 Charles Rollin, Histoire ancienne des Égyptiens, des Carthaginois, des Assyriens, des Babyloniens, des Mèdes et des Perses, des Macédoniens, des Grecs, 13 vols. (Paris: Etienne, 1730-38). On history textbooks in France during that period see Louis Trenard, "L'Historiographie française d'après les manuels scolaires, de Bossuet à Voltaire," Studies on Voltaire and the Eighteenth Century 155 (1976), 2083-2111.

${ }^{41} \quad$ Charles Rollin, The method of teaching and studying the belles lettres, or an introduction to languages, poetry, rhetoric, history, moral philosophy, physics (London: A. Bettesworth and C. Hitch, 1734, 1 (De la manière d'enseigner et d'étudier les belles lettres par rapport à l'esprit et au cour, 4 vols. (Paris: Etienne, 1726-8).

42 Ibid.

43 Ibid., 7.

44 Ibid., 8.

45 Thomas Pavel, L'Art de l'éloignement, Essais sur l'imagination classique (Paris: Gallimard, 1996).

46 Voltaire, Conseils à un journaliste, 244. 
critical methods that characterized the second half of the seventeenth century. As Chantal Grell points out, Mabillon's "diplomatic science" worked only on official documents deposited in church archives. It could not work on ancient history. ${ }^{47}$ Similarly, Bayle's critical method worked best for the recent past, since it privileged first-hand testimony against tradition. A study of his Historical and Critical Dictionary shows that sixty percent of the articles are on the recent past (sixteenth and seventeenth centuries) while twelve percent are on the Middle Ages and twenty-eight percent on antiquity. ${ }^{48}$ Voltaire was suspicious even of the kind of history pioneered by Mabillon and Le Nain de Tillemon, which made a critical use of charters going back to the Middle Ages. For Voltaire, any document that pre-dated the invention of the printing press was by definition untrustworthy: "history before the invention of printing was less than exact because it was seldom contradicted." 49 Only what had been vetted through publication and public debate was reliable. The existence of a public sphere, where evidence was questioned and assessed, was the only firm guarantor of the truthfulness of historical narratives. When the art of writing was the monopoly of a small group of people, "it was easy to make us believe the most preposterous things." 50 As a consequence, Voltaire argued, it is only by the end of the fifteenth century that history "begins to be truly interesting to us." ${ }_{11}$

All of this so far is consistent with the standard Enlightenment narrative: modern history is more reliable because, as we approach the present, the world is more enlightened. However, Voltaire had other, perhaps more important, reasons for preferring modern history. First, his status as the king's historiographer: he held this position from 1745 to 1750 , but it continued to inform his perspective afterwards. In 1752 Voltaire wrote to a correspondent that publishing The Age of Louis XIV was a way of fulfilling his historiographer's duties, and that he saw these duties with even more urgency and pleasure now that they were no longer his official duties..$^{2}$ Second, modern history was to be privileged because of its greater exemplary value. In this Voltaire agreed with Bolingbroke, who wrote about the "the more entire as well as more authentic histories of ages more

47 Chantal Grell, L'Histoire entre érudition et philosophie (Paris: PUF, 1993), 229.

48 See J. Solé, "Religion et vision historiographique dans le Dictionnaire de Bayle," in Religion, érudition et critique à la fin du XVIIe siècle et au début du XVIIIe siècle (Paris: PUF, 1968), 71-200.

49 Voltaire, article on Le Nain de Tillemont (1751), in "Catalogue de la plupart des écrivains français qui ont paru dans le Siècle de Louis XIV," in idem, Oeuvres historiques, 1181.

50 Voltaire, article on "Histoire," in idem, Questions sur l'Encyclopédie, distribuées en forme de dictionnaire, 9 vols. (London, 1771-2), 8: 20.

51 Voltaire, "Remarques sur l'histoire," in idem, Oeuvres historiques, 44.

52 Voltaire, letter to Charles Auguste Ferriol, comte d'Argental, 18 Dec. 1752, in Correspondance, ed. Theodore Besterman, vol. 3 (Paris: Gallimard, 1975), 860. 
modern" and stressed that only modern history could be called "magistra vitae." Ancient history could be "at best 'nuntia vetustatis,' the gazette of antiquity, or a dry register of useless anecdotes." 53 As George Nadel points out, Bolingbroke was both "a philosopher striving for something new to say" and "a humanist anxious to show that he could quote whatever the ancients had said." 54 How do you say something new when the rules of humanist scholarship imply an endorsement of ancient precepts? Nadel shows that Bolingbroke's solution was to reaffirm the exemplary function of history while insisting (and this was the innovation) that valid examples could be found only in modern history. Without trying to settle the question of Bolingbroke's possible influence on Voltaire, ${ }^{55}$ one may say that Voltaire privileged modern history for exactly the reasons invoked by Bolingbroke, and The Age of Louis XIV was consistent with Bolingbroke's prescriptions on the use of history.

Fundamentally, the purpose of history was to trace the progress of the human mind. We tend to see this in the light of Condorcet's reinterpretation of Voltaire's project: telling the history of the world as a struggle between reason and unreason..$^{56}$ This interpretation is not entirely inaccurate, but it misses one aspect that Voltaire saw as fundamental. Showing "the progress of the human mind and of all the arts under Louis XIV" 57 was a way of presenting the century of Louis XIV as "an example for the centuries to come." 58 What made the age of Louis XIV worth studying was its exemplary value. In that sense Voltaire had no quarrel with Rollin's invocation of the historia magistra vitae topos, and his work was an adamant reaffirmation of the exemplary value of history. ${ }^{59}$ On the other hand, Voltaire's reinterpretation of the topos was taking it to a very different place. In the humanist tradition, exemplarity was based on temporal, geographical, and cultural distance. ${ }^{60}$ Role models from antiquity were, by definition, remote and foreign, and they required an effort of accommodation and appropriation. Imitation of the deeds of heroes was predicated on the notion that ancient standards of virtue were probably out of reach, yet it was

53 Bolingbroke, Letters on the Study and the Use of History, vol. 1 (London: Millar, 1752), letter 5, 150.

54 Nadel, "Philosophy of History before Historicism," 311.

55 See Brumfitt, Voltaire Historian, 40-45.

56 Jean-Antoine-Nicolas de Caritat, marquis de Condorcet, Esquisse d'un tableau historique des progrès de l'esprit humain (Paris: Agasse, 1794).

57 Voltaire, Conseils à un journaliste, 245.

58 Ibid.

59 On the gradual disappearance of the historia magistra vitae topos see Reinhart Koselleck, Futures Past: On the Semantics of Historical Time (New York: Columbia University Press, 2004), 26-42.

60 See Thomas Pavel, L'Art de l'éloignement. 
the very distance between old standards and present realities that was inspiring. In privileging modern examples, Voltaire was turning this logic on its head. $\mathrm{He}$ moved from a notion of exemplarity based on distance to one based on proximity. In addition, Voltaire did subscribe to the humanist notion that examples should be sought in the behavior of exceptional individuals, but here, too, there was a shift. In The Age of Louis XIV, the hero was not so much Louis XIV as the age itself.

Brumfitt notes that Voltaire became gradually more interested in ancient history, and interprets this move as a pragmatic adjustment to an early stance that was too extreme. ${ }^{61}$ It is indeed true that Voltaire wrote more about ancient history during his mature years, but I would argue that he developed a theory of ancient history that was consistent with his early privileging of modern history.

For Voltaire, as one went further into the past, things became less relevant and interesting. There was some purpose, however, to the study of antiquity, but this purpose had been fundamentally modified by the progress of the human mind. Antiquity was now an object of scientific study. There had been progress in the knowledge of antiquity in the same way that there had been progress in the knowledge of physics. This is how Voltaire interpreted the foundation of the Académie des inscriptions et belles-lettres. Its mission was to study antiquity in the same way that physicists studied nature:

The Académie des belles-lettres, initially comprised in 1663 of a few members of the Académie française in order to convey the actions of Louis XIV to posterity through the minting of medals, became useful to the public when it ceased to focus exclusively on the monarch and dedicated itself to research about antiquity and to a judicious critique of opinions and facts. It did more or less in the field of history what the Académie des sciences did in physics: it dispelled errors. ${ }^{62}$

In the Philosophical Letters, Voltaire uses a satirical tone to discuss the Académie française, but he mentions the Académie des belles-lettres and the Académie des sciences with equal respect. While the Académie française has produced many bad speeches, "the Académie des belles-lettres has set a goal for itself that is wiser and more useful; it is to present to the public a collection of reports filled with curious research and criticism. These reports are already valued by foreigners." ${ }^{63}$ (Voltaire is alluding here to the famous mémoires that were indeed widely circulated in the Republic of Letters.) Both academies deserve respect because their common purpose is to establish facts. The expression "curious research and criticism"

$61 \quad$ Brumfitt, Voltaire Historian, 84-94.

62 Voltaire, Le Siècle de Louis XIV, in idem, Oeuvres historiques, 1000.

63 Ibid. 
seems to give a relatively minor purpose to the study of antiquity. The adjective "curious," however, should be taken in its full sense. The impulse behind the study of antiquity is the same as the impulse behind the study of nature: curiosity. In the same spirit the twenty-third philosophical letter praises Louis XIV for having supported "the arts," which include not only painting, sculpture, and architecture, but also astronomy, mathematics, medicine, and "research about antiquity." 64

For Voltaire, one of the distinguishing features of the age of Louis XIV was its superior knowledge of antiquity: "This century in particular had a better knowledge of antiquity than its predecessors." ${ }^{65}$ Archeological digs had unearthed ancient monuments, especially in Italy. This had resulted in significant and tangible progress in the knowledge of antiquity: "Italy provides more monuments that the rest of Europe combined; the more monuments have been unearthed, the more science has expanded." ${ }^{\prime 66}$ The logic here is one of scientific accumulation: the more material we dig up, the better we understand the past. In that sense it was useful to improve the knowledge of the distant past, because distance bred ignorance, and ignorance bred erroneous beliefs. For instance, in the "Antiquity" article of the Questions sur l'Encyclopédie, Voltaire satirized the pseudoscience that the general lack of knowledge about antiquity had made possible, including the pretentions of a Scottish author who claimed that the Garden of Eden was in Edinburgh, because the names of both places began with the letter E. ${ }^{67}$

The eighteenth century was a time of great change in the study of antiquity. Voltaire was perfectly aware of this change, and he did show respect for the work of antiquarians. However, in Voltaire's eyes, modern history and ancient history were two fundamentally different enterprises. Only modern history qualified as history: it was "a matter of necessity" 68 because it could provide a coherent narrative that led up to the present times. Ancient history, on the other hand, was "a matter of curiosity" 69 with the same status as the study of the natural world. In that sense, Voltaire's privileging of modern history implied not so much a "defeat of erudition"70 at the hands of philosophy as it did a recasting of erudition as scientific activity, separate from the philosophical task of writing history.

\footnotetext{
64 Voltaire, Lettres philosophiques, ed. René Pomeau (Paris: Garnier-Flammarion, 1999), letter 23, 148 .

65 Voltaire, Le Siècle de Louis XIV, in idem, Oeuvres historiques, 1028.

66 Ibid.

67 Voltaire, article on "Antiquité," in idem, Questions sur l'Encyclopédie, 1: 299.

68 Voltaire, Conseils à un journaliste, 244.

69 Ibid.

7o See Blandine Barret-Kriegel, La Défaite de l'érudition (Paris: PUF, 1988).
} 


\section{HISTORICAL JUDGMENT AND THE QUARREL OF THE ANCIENTS AND THE MODERNS}

In order to have a fuller understanding of the preference for the present that characterized Voltaire's conception of history, we must understand his position in the quarrel of the ancients and the moderns. In the "Ancients and Moderns" article of the Philosophical Dictionary, Voltaire begins by saying that the famous quarrel is still unresolved. ${ }^{71}$ He begins by quoting two paragraphs from what was generally seen as the most persuasive apology for the moderns, Fontenelle's Digression on the Ancients and the Moderns. ${ }^{72}$ After quoting "the learned and ingenious Fontenelle,"73 who dismissed as absurd the notion that trees and human minds might have been more vigorous in ancient times, Voltaire argues that "with the permission of the distinguished academician, this is no longer at all the state of the question."74 Voltaire does not disagree with Fontenelle's conclusions, but he takes issue with his method. It is not necessary to entertain conjectures about the potential of the human race in various historical periods. The comparison between the ancients and the moderns is a question of fact, subject to empirical testing: "The question is not whether nature today is able to produce geniuses and works that are as good as those from antiquity, but whether we have actually done so." 75 As he puts it elsewhere in the same article, in order to decide whether the moderns are superior to the ancients, it suffices to establish a comparative listing of achievements. The period with the greater number of achievements wins: "Therefore this dispute is a matter of fact. Has antiquity produced more great monuments of all kinds until the time of Plutarch than the modern period from the age of the Medici to Louis XIV inclusively? ${ }^{76}$ Voltaire does not answer this rhetorical question. The response is clear enough. An important consequence is that classical antiquity no longer enjoys the privileged status it once had as a source of exemplary achievements. Antiquity has produced great siècles (of Augustus, of Alexander) like the modern period has, and for the most part the siècle de Louis XIV is superior to all the others.

The notion that human history had produced four great siècles (Alexander, Augustus, Leo X, and Louis XIV) was not Voltaire's invention. It was proposed by Dubos in his 1719 Critical Reflections on Poetry, Painting and Music. ${ }^{77}$ Jean-Baptiste

\footnotetext{
Voltaire, article on “Anciens et modernes," in idem, Questions sur l'Encyclopédie, 1: 245. Ibid.

Ibid.

Ibid., 248.

Ibid.

Ibid., 248.

Jean-Baptiste Dubos, Réflexions critiques sur la poésie et sur la peinture, vol. 2 (1719), (Paris: Mariette, 1733), sect. 12, 134. On the complex relationship between Dubos and Voltaire see
} 
Dubos (1670-1742) was a historian with an antiquarian bent who practiced the new critical method and became perpetual secretary of the Académie française in 1722. As Fumaroli points out, Dubos was a partisan of the ancients who was just as fluent in the language of the moderns. ${ }^{78}$ He elaborated a defense of the Ancients that sought to include the achievements of the new science and recognized the fact that the moderns had a better knowledge of the natural world. Dubos did not claim to have a definitive explanation for the superiority of those four siècles over all the others. He speculated that there were moral causes and physical causes. The moral causes were the various encouragements that a particular society provided for the arts. ${ }^{79}$ Moral causes played an important role, but, for Dubos, the physical causes trumped the moral ones. ${ }^{80}$ Dubos speculated that the quality of the air in a particular place and time was the overriding reason why men of genius appeared. As a result, the great cultural achievements of a particular period were ultimately the consequence not of a certain degree of civilization but of the presence of a few geniuses. As Dubos puts it, it is the great artists who make the great patrons, and not the reverse. A particular period may be very civilized in the sense that it has successfully cultivated the sciences, but true greatness comes from genius, which is individual and ultimately unrelated to the overall degree of civilization. ${ }^{81}$

In The Age of Louis XIV, Voltaire addressed these theories explicitly. Without naming Dubos, he agreed with him that "the age of Louis XIV has in everything the destiny of the ages of Leo X, Augustus and Alexander," 82 but he implicitly reversed Dubos's hierarchy between physical causes and moral causes. For Voltaire, the appearance of persons of genius was a consequence of the overall advancement of civilization. ${ }^{83}$

The Age of Louis XIV did not present itself explicitly as an apology for the moderns. For Voltaire, the superiority of the moderns was beyond dispute. However, The Age of Louis XIV was predicated on a refutation of Dubos's theory on the relationship between a siècle and its geniuses. For Voltaire, the age of Louis XIV was great because it had produced geniuses, but these geniuses could not be separated from the overall achievements of the period. A siècle had to be taken as a whole when compared with other siècles. This is why The Age of Louis XIV was followed by a catalog that listed not only the great names, but "most of the

Enzo Caramaschi, "Du Bos et Voltaire," Studies on Voltaire and the Eighteenth Century 10 (1959), 113-236.

78 Marc Fumaroli, La Querelle des Anciens et des Modernes (Paris: Gallimard, 2001), 212-13.

79 Dubos, Réflexions critiques, vol. 2, sect. 12, 130.

80 Ibid., sect. 13, 145.

$81 \quad$ Ibid., sect. 39, 558.

82 Voltaire, Le Siècle de Louis XIV, in idem, Oeuvres historiques, 1015.

83 Ibid. 
writers who lived in the age of Louis XIV." ${ }^{4}$ If the comparison was done in this way, the moderns were clearly superior to the ancients.

\section{JUDGING HISTORICALLY, JUDGING EQUITABLY}

In 1964 George Nadel noticed that the traditional division between Renaissance studies and eighteenth-century studies had made it difficult to perceive any continuity between humanist history and Enlightenment history. ${ }^{85}$ Even today, specialists of the eighteenth century are usually not familiar with the language of the rhetorical tradition. As a result they do not pay attention to words like "equity" and "equitable." To a modern reader these words convey a vague sense of justice or fair-mindedness, but they have a very specific, technical sense in the rhetorical tradition. A good deal of the difference between Voltaire and Dubos has to do with their understanding of equity. In the rhetorical tradition, equity was the art of accommodating the generality of the law to the particular circumstances of a case. In matters of style, equity manifested itself as attention paid to what Aristotle called to prepon, or what Quintilian called decorum: the art of achieving a match between a speech and its audience, as well as between the subject matter and the words used. As Kathy Eden points out in Hermeneutics and the Rhetorical Tradition, decorum was not only a principle of rhetorical composition. It was a hermeneutic principle as well. ${ }^{86}$ Using decorum in interpretation meant paying attention to the fact that a text was written for a particular audience at a particular time. In that sense, an "equitable" interpretation had to pay attention to historical context. Reading equitably meant, in part, reading historically. Eden shows that the clearest formulation of this kind of historicism was given by Erasmus, who brought together the notions of reading in context, reading equitably (ad aequitatem naturalem) and reading historically (pro ratione temporis). ${ }^{87}$

One of the main points of contention in the quarrel of the ancients and the moderns was the imperfections and faults of ancient poets like Homer. Dubos addressed the issue by reminding his audience that it should not be blind to cultural and historical difference:

The bias most humans have in favor of their own time and their own nation is therefore the source of many poor remarks and poor judgments. They take what is being done as

84 Voltaire, "Catalogue de la plupart des écrivains français qui ont paru dans le siècle de Louis XIV, pour servir à l'histoire littéraire de ce temps" in idem, Oeuvres historiques, 1133-1214.

85 Nadel, "Philosophy of History before Historicism," 292.

86 Kathy Eden, Hermeneutics and the Rhetorical Tradition (New Haven: Yale University Press, 1997), 12-16.

87 Kathy Eden, "Equity and the Origins of Renaissance Historicism: The Case for Erasmus," Yale Journal of Law and the Humanities 5 (1993), 137-45. 
the rule for what should be done everywhere and what should have been done always. Yet only a small number of customs and a small number of vices and virtues have been praised and blamed in all times and in all countries. ${ }^{88}$

This development, done in the spirit of Montaigne's skepticism, is followed by a quote from Quintilian that is precisely a definition of the concept of decorum:

Poets are right to follow Quintilian's advice to orators: take advantage of the ideas of those for whom they compose, and adapt to those ideas. It is of the utmost importance to consider what the customs of the audience are, and what the publicly received opinion is (Quint. Inst. Lib. 3, cap. 9). ${ }^{89}$

If one bears in mind the question of decorum (in other words, if one cares to read historically) one will understand the many apparent oddities in Homer and other ancient poets. For instance Homer, who wrote not long after the events he narrates, was expected by his audience to give a comprehensive account, with lists of warriors, ships, and so on. This explains the catalog of ships in the Iliad, which puzzles modern readers.

For Dubos, "an image that is noble in one country is ignoble in another." 90 For instance, Europeans today have contempt for donkeys, but the Chinese honor them, and the ancient Greeks honored them as well. If one becomes aware of this sort of cultural difference, one will forgive the ancients and the Asians for the oddity of their literature. That is not enough, however, says Dubos. The critics who forgive Homer for being odd think they are being equitable, but their sense of equity is insufficient. Becoming aware of historical difference should not only protect the poetry of the ancients from unfair criticism, it should help recover the original beauty of ancient texts: "these figures are not only excusable; they are beautiful in the original." 91 For Dubos the purpose of an equitable or historical reading is to reclaim the beauty of ancient texts without any exceptions or reservations. Any fault we see in Homer is the result of our ignorance of context. If we care to learn about the context, Homer will appear in its complete beauty.

Voltaire, too, was sensitive to historical context, but he had a different understanding of what it was to read equitably. On the one hand, he was well aware of the demands of history as a discipline. For a historian, it made no sense to use the customs of the present to evaluate the customs of the past:

It is common knowledge nowadays that we should not judge ancient customs on the basis of modern customs. If you tried to reform the court of Alkinoos in the Odyssey by using

\footnotetext{
88 Dubos, Réflexions critiques, vol. 2, sect. 37, 544.

89 Ibid., sect. 37,545 .

$90 \quad$ Ibid., sect. 35, 525 .

$91 \quad$ Ibid., sect. $35,527$.
} 
the court of the Great Turk or that of Louis XIV as a model, you would not be well received by scholars. If you faulted Virgil for representing King Evander covered with bearskin and accompanied by two dogs when receiving ambassadors, you would be a poor critic. ${ }^{92}$

On the other hand, in his essay on epic poetry, originally published in English, Voltaire addressed the issue of the historicity of style and taste by making a distinction between what is universal and what is subject to local and historical variation:

It is true, there are beauties which the taste of every nation equally relish. Since all Europe has set up the Greek and Roman authors for models of writing, Homer and Demosthenes, Virgil and Tully, have in some measure united under their laws our European nations, and made of so many and different countries a single Commonwealth of letters. ${ }^{93}$

For Voltaire, being equitable meant being aware of local and historical variation, and a critic who wanted to understand what epic poetry was had to grasp it in all its manifestations through time and space - not only ancient poetry, but also the poetry of modern Italy, England, and so on: "It is a pleasure, no doubt, and a great improvement of our mind, to survey all the epic writers in their respective countries, from Homer down to Milton, and to observe the different features, and the various dresses of those great men." ${ }^{44}$ In that sense, being equitable meant being able to overcome the partiality one had for the taste of one's time and one's nation, and to make literary judgments that were universally valid:

The judicious reader will supply the defects, and enforce the feeble hints he will find in this Essay. My part is to propose, his to judge; and his judgment will be right, if he attends without partiality, laying aside the prejudices of the school, or the over-bearing love of the productions of his own country ... He will distinguish the beauties, and the faults which are such, everywhere, and in all ages, from those doubtful things which are called blemishes by one nation, and styled perfections by another. He will not be tyrannized by Aristotle, Castelvetro, Dacier, Le Bossu; but he will extract his own rules from the various examples he shall have before his eyes, and governed by his good sense alone, be a judge between the Gods of Homer, and the God of Milton, and between Calypso, Dido, Armida, and Eve. ${ }^{95}$

92 Voltaire, article on "Ezéchiel" (1764), in Dictionnaire philosophique, Oeuvres complètes de Voltaire, 19: 54.

93 Voltaire, An Essay on Epic Poetry (1727), in The Complete Works of Voltaire, vol. 3B (Geneva: Institut et Musée Voltaire; Toronto: University of Toronto Press, 1996), 308.

94 Ibid., 313 .

95 Ibid. 
Against critics like Dacier, ${ }^{96}$ who read Homer historically in order to recover the original beauty of the text, Voltaire proposed to use one's judgment to distinguish, in every author, between what was universally beautiful and what pertained to historical and local variation. This is precisely how Voltaire understood equity in literary judgment. He referred explicitly to this notion in the sentence that follows the passage I have just quoted: "But if the reader be so just, as to make allowances for the time in which those different authors have writ, it is to be hoped he will look with some indulgence on the diction of this essay."97 (I should add that Desfontaines's French translation of "being just" in the context of "making allowances for time" is precisely équité. ${ }^{8}$ ) As Voltaire put it in the Questions sur l'Encyclopédie, "reason and good taste demand, it seems to me, that in ancient as well as in modern authors, the good be distinguished from the bad, the former being often next to the latter." 99 In that sense, Voltaire was following the method advocated by Fontenelle in the Digression. Overcoming prejudice meant ignoring the fact that the great authors from antiquity had been admired for thousands of years. Equity, in this case, required giving up the respect and the indulgence that had traditionally accompanied the reception of ancient authors:

One must be capable of saying or hearing without indulgence that there is something amiss in Homer or Pindar; one must dare to believe that mortal eyes can see the faults of these great geniuses; one must dare to compare Demosthenes and Cicero with a man who bears a name that is French and perhaps humble; what a great and extraordinary effort of reason this requires! $!^{100}$

"Without indulgence" meant without the traditional demands of equity, or according to a new form of equity that put the ancients and the moderns on equal footing:

I only intend to show that, because the Ancients may have achieved, or not achieved, absolute perfection in some things, when we ascertain whether they did, we should have no respect for great names, and no indulgence for their faults; in other words, we should treat them like Moderns. ${ }^{101}$

\footnotetext{
96 Anne Lefèvre-Dacier, Des Causes de la corruption du goût (Paris: Rigaud, 1714).

97 Voltaire, An Essay on Epic Poetry, 314.

98 Voltaire, Essai sur la poésie épique (1728), trans. Desfontaines, in The Complete Works of Voltaire, vol. 3B, 512.

99 Voltaire, article on "Anciens et modernes," in idem, Questions sur l'Encyclopédie, 1: 259.

100 Fontenelle, Digression sur les Anciens et les Modernes, in idem, Entretiens sur la pluralité des mondes (1688) (Oxford: Clarendon Press, 1955), 169.

101 Ibid.
} 
For Voltaire, an "equitable judge"102 was one who could use his own judgment to sort out the good and the bad in Racine as well as in Sophocles. In that sense, historical distance was irrelevant: "Thus he will judge the ancients not by their name, not by the time they lived in, but by the works themselves; it is not three thousand years that should please, it is the thing itself."103

Being equitable meant making judgments across time and space while keeping the same standards. It was therefore possible to make comparisons between the eloquence of Homer's characters and the eloquence of Colocolo, an Auracanian tribal chief, as reported by Alonzo in his account of the Spanish conquest of Chile:

Now since the best way of improving our taste is that of comparing together things of the same nature, let us bring in the discourse of Nestor, in opposition to this of Colocolo, and laying aside that worship, which our minds justly prejudiced pay to the great name of Homer, let the reader weigh the two speeches in the balance of equity and reason. ${ }^{104}$

According to Voltaire, if we forget the respect that is traditionally given to Homer, we must acknowledge that Colocolo is more eloquent than Nestor.

Voltaire did not revolutionize terminology: he used traditional words and expressions in a new and different way. We have seen above that he argued for judging texts "in the balance of equity and reason." When he paired the words "equity" and "reason," Voltaire was in some ways following tradition: équité et raison was the traditional French translation of the Latin legal expression aequum et bonum. ${ }^{105}$ In accordance with tradition, Voltaire used "equity" and "reason" as quasi-synonyms, but he redefined the practice of equity as the exercise of a single standard of judgment across time and space. What we can see here is both a point of contact and a point of separation between the language associated with the Enlightenment (reason as synonym for the universal) and the language of humanism. Voltaire and Dubos both spoke the language of the humanist tradition, they embraced the practice of equity, and they showed awareness of historical and cultural difference. Such awareness, however, led them in opposite directions. Dubos endorsed a conception of equity that identified historical understanding with indulgence and accommodation. Practicing equity meant negotiating the difference between the circumstances of the past and the circumstances of the present. Aware as he was of historical and cultural difference, Voltaire believed that practicing equity meant submitting everything to the test of reason and ultimately rejecting what did not stand the test. According to Voltaire, when all is said and done, it is the historian's duty to be severe and unforgiving.

\footnotetext{
102 Voltaire, article on "Anciens et modernes," in idem, Questions sur l'Encyclopédie, 1: 260.

103 Ibid.

104 Voltaire, An Essay on Epic Poetry, 367.

105 Article on "équité," in Nicot, Trésor de la langue française (1606).
} 
If we read Voltaire with Kant's "tribunal of reason" in mind, we will interpret this as the assertion of universal moral norms. It is probably just as accurate to say, in the language of humanism, that Voltaire's goal was simply to show severity in historical judgment.

\section{THE UNIVERSAL HISTORIAN AS AN ANTHOLOGIST}

In this study of the innovativeness of Voltaire's historical practice, one aspect remains to be examined: the fact that the Essay on Manners was a universal history. According to Voltaire, the fact that it is now possible to write the history of the world as a whole is a consequence of the historical developments of the past two centuries. Referring to history since the end of the fifteenth century, he writes,

Everything speaks to us; everything is done for us. The silver in which we dine, our furniture, our new needs and pleasures, everything reminds us every day that America and the Great Indies, i.e. all the parts of the entire world, have been joined for the past two and a half centuries, thanks to the industry of our fathers. No matter where we go, we are reminded of the change that has taken place in the world. ${ }^{106}$

According to this view, the momentous changes of the previous two centuries (the invention of printing, the Reformation, balance of power politics, the Republic of Letters, colonial trade and conquest) have changed the world in such a way that the parts of the world have become interdependent, and history must now be written from a universal perspective. We can see here that for Voltaire there was an essential connection between modern history and universal history.

In a 1754 preface to the Essay on Manners, Voltaire begins by saying that he has been studying history for his own instruction only. Then, a woman known for her superior intelligence and her knowledge of metaphysics and science (Emilie du Châtelet) told him that she found modern history so dull and boring that she has been unable to read through a single book dealing with the history of modern times. Ancient history, on the other hand, might be unreliable but it is very readable because it has good stories in it. Voltaire's response to Emilie's discomfort is the following:

But, I said to her, if, in this vast amount of raw material, you selected what will allow you to build something for your own use; if you omitted all the details of each war, which are as boring as they are uncertain; if you omitted all the small negotiations, which turned out to be useless treachery; all the particular incidents, which obliterate the great events; if, keeping what pertains to manners, you turned this chaos into a general and definite picture; if you tried to tease out the story of the human mind from these events; do you think it would be a waste of your time? 
This idea won her over, and this is the plan that guided my work. I was surprised at first that so little help could be found in the great multitude of books. ${ }^{107}$

This story of how the Essay on Manners came about is usually read literally. At least one element is obviously false: Voltaire never studied history for his instruction only, since one of his earliest works, the biography of Charles XII (1731), was a work of history. On the other hand, the story, factual or not, says a lot about the purpose of the book. The key to understanding Voltaire's universal history is the fact that its intended reader was a woman. As Dena Goodman puts it, "in Voltaire's history of the age of Louis XIV, women were central to the transformation of France from a barbaric to a civilized nation." ${ }^{108}$ More generally, French Enlightenment sociability was based on "substituting a female salonnière for a male king as the governor of its discourse."109 Goodman notes that Hume saw this fact with some unease: for him, women were the legitimate rulers of the "conversible world" (the world of polite conversation), but in France their rule extended (problematically, in his view) to the "learned world." modern view of the progress of civility, theorized by Fontenelle, the ideal salon was a place in which science could be discussed along with literature, and the discussion of science had to observe the conventions of civility. ${ }^{111}$ When it came to writing, the most effective way of observing the conventions of civility was to posit a woman as the intended reader. This carried all sorts of requirements: a text written for a woman had to be clear and concise, and it had to make sense of things. Women were posited as the arbiters of taste as well as clear thinking, and the best connoisseurs of everything vernacular and modern. They were construed as the enemies of erudition, pedantic taste, antiquarianism, Latinate obscurity, and confused thinking. For Voltaire, Emilie du Châtelet was the perfect embodiment of these values: she was a woman who practiced polite conversation and also happened to be a scientific genius (who understood Newton's physics far better than Voltaire himself did). In short, Voltaire set the following challenge for himself: can you write modern history in a way that a very smart woman will like? A comparison with Hume's essay on the study of history is relevant here. Hume argued that reading history was a profitable activity for women. ${ }^{112}$ Voltaire's position was considerably more radical: he contended that history

\footnotetext{
107 Preface for vol. 3 of the Walther edition (1754) in Essai sur les moeurs, 2: 883.

108 Dena Goodman, The Republic of Letters: A Cultural History of the French Enlightenment (Ithaca: Cornell University Press, 1994), 6.

109 Ibid., 5.

$110 \quad$ Ibid., 124.

111 Fontenelle, Entretiens sur la pluralité des mondes.

112 David Hume, "Of the Study of History," in idem, Essays Moral and Political, vol. 1 (Edinburgh: Kincaid, 1742), 74-82.
} 
should be written with a female readership in mind. The question appears initially as a purely stylistic one, but form cannot be separated from content. The kind of history that would appeal to a woman like Emilie du Châtelet was universal history. Not universal history as compilation, ${ }^{113}$ but a new kind of universal history, the kind Bossuet had invented. The Discourse on Universal History is often presented as some vestigial manifestation of a providential conception of history. This obscures one aspect that was very clear to Voltaire: the fact that Bossuet had invented a new way of writing history. In The Age of Louis $X I V$, Voltaire presents Bossuet as having invented a new genre of eloquence. It consisted in applying the techniques of eloquence to history itself, "which seems to exclude it." He adds that "his Discourse on Universal History, composed for the education of the Dauphin, was neither copied after any model, nor has yet had an imitator."114

This is a striking acknowledgement of Bossuet's innovativeness, and it helps put in perspective the many criticisms addressed to Bossuet in the Essay on Manners (the Discourse is Judeocentric, it overlooks Asian history, and so on). It is often said that Voltaire admired Bossuet's style but did not take him seriously as a historian, ${ }^{115}$ but again one should be aware of "the content of the form." Choosing to write in a certain manner determines the kind of story one writes: "The world was astonished at that majestic energy, wherewith he describes manners, affairs of state, the rise and fall of great empires, and at those masterly strokes of expressive truth, which appear in his descriptions and judgments of nations." 116 Indeed, Bossuet's project was to rise above national histories in order to narrate the history of the world as a whole:

Particular histories show the sequence of events that have occurred in a nation in all their detail. But in order to understand everything, we must know what connection that history might have with others; and that can be done by a condensation in which we can perceive, as in one glance, the entire sequence of time. ${ }^{117}$

Bossuet's method can be seen, for instance, in his account of the Punic Wars. Drawing from Polybius, he explains that, given the nature of the Roman political

113 On erudite universal history see Tamara Griggs, "Universal History from CounterReformation to Enlightenment," Modern Intellectual History 4/2 (2007), 219-47.

114 Voltaire, Le Siècle de Louis XIV, in idem, Oeuvres historiques, 1006.

115 See J. H. Brumfitt's introduction to La Philosophie de l'histoire, in The Complete Works of Voltaire, vol. 59 (Toronto: University of Toronto Press, 1969), 32-5.

116 Voltaire, Le Siècle de Louis XIV, in idem, Oeuvres historiques, 1006.

117 Jacques Bénigne Bossuet, Discourse on Universal History, trans. Elborg Forster, ed. and with an introduction by Orest Ranum (Chicago: University of Chicago Press, 1976), 4 (Discours sur l'histoire universelle à Monseigneur le dauphin, pour expliquer la suite de la religion et les changements des empires (Paris: Mabre-Cramoisy, 1681)). 
system and the nature of the Carthaginian political system, the victory of Rome was not a contingent event but a necessary one. ${ }^{118}$ Voltaire did admire the "bigpicture" way in which Bossuet swept through world history and showed causal connections between major events. He unequivocally endorsed those sections of the Discourse that did not make a direct appeal to providential explanations: according to Voltaire, Bossuet had "grasped the true spirit"119 of universal history in his chapters on the Roman Empire.

At first sight, one might say that Voltaire's focus on modern history was a polemical response to Bossuet's focus on ancient history. However, Bossuet, whose story stopped with Charlemagne, intended to write a second part leading up to the reign of Louis XIV. In the preface addressed to the Dauphin, he announced the sequence, "which will bring you up to the century we see illuminated by the immortal actions of the king, your father." ${ }^{20}$ The Dauphin himself, under Bossuet's supervision, wrote a history of France leading up to the reign of Charles IX. It is wrong to say, therefore, that Bossuet's main preoccupation was ancient history. In fact, the celebration of the present that is so characteristic of Voltaire's Essay can also be found in some measure in Bossuet's Discourse, whose preface mentions "the time of Louis XIV, when, united under this great king, France alone triumphs over all of Europe."121 It is for purely circumstantial reasons that the second part of the Discourse was not written: Bossuet left his position as tutor of the Dauphin when his pupil turned twenty, just two years after the first part was written. Voltaire's Essay was in some ways a polemic against Bossuet's Discourse, but it was also, in very important ways, a continuation of it: written for a woman as Bossuet's Discourse was written for a boy, brief, in lucid language, in the vernacular, taking world history as a whole, leading up to the present, and focused on showing the connections between major historical events.

In the foreword to the Essay on Manners, Voltaire begins his critique of Bossuet with the remark that "in these immense collections that are impossible to handle, one must set limits and make choices. It is a vast store, where you will select what is for your own use." ${ }^{\prime 22}$ He goes on to criticize Bossuet for having written world history from the perspective of Jewish history, and having ignored the histories of India and China. This remark brings up a methodological issue that Voltaire did not ignore. All historians have to make choices, but those writing universal histories have to be selective in the extreme. Hence the question: how do you discriminate? How do you choose in the mass of historical records? How can

\footnotetext{
118 Ibid., chap. 6 (339-61).

119 Voltaire, Essai sur les moeurs, 1: 196.

120 Bossuet, Discourse on Universal History, 5.

121 Ibid., 3 .

122 Voltaire, Essai sur les mœurs, 1: 196.
} 
you tell the relevant from the irrelevant? Voltaire's response was: one has to be discriminating in the extreme; only what serves to tell the story of the progress of the human mind is relevant.

Perhaps the clearest example of this extreme selectiveness is the way Voltaire wrote the history of literature. One may object to the choice of this example by saying that literature is a special case that involves personal taste, as opposed to a historian's effort to decide what is relevant and what is not. I contend, on the contrary, that the history of literature is especially revealing because, in Voltaire's conception of history, a period is ultimately judged on the basis of its intellectual and cultural achievements. The broad social and cultural history contained in the Essay on Manners has one goal: laying out the causes of the cultural achievements of the present.

Voltaire's final word on the quarrel of the ancients and the moderns can be seen in the following passage, in which all world literature is submitted to a single standard of judgment:

Thus there are genres in which the moderns are considerably superior to the ancients, and a very small number of others in which we are inferior to them. This is what the entire dispute comes down to.

Reason and good taste demand, it seems to me, that in ancient as well as in modern authors, the good be distinguished from the bad, the former being often next to the latter.

One must be deeply moved by this line from Corneille. There is no line in Homer, in Sophocles, in Euripides, that comes even close:

Que vouliez-vous qu'il fit contre trois? - Qu'il mourût.

and with equal discernment and fairness, one must disapprove of the following lines. ${ }^{123}$

Voltaire's treatment of Corneille is particularly significant. The line from Horace: "Que vouliez-vous qu'il fît contre trois? - Qu'il mourût" was widely regarded as a sublime passage. Boileau had mentioned it in the critical reflections accompanying his translation of Longinus. ${ }^{124}$ The category of the sublime plays a fundamental role in the aesthetic thinking of both Dubos and Voltaire, but it is put to diverging uses. For Dubos, sublimity was the manifestation of genius, and genius was to be found mostly in ancient times and in faraway places:

Many of these great geniuses, says one of the best English poets, who rise above others thanks to the strength of their natural gifts, are to be found among the ancients, and particularly among those of the more eastern parts of the world. Homer has innumerable

\footnotetext{
123 Voltaire, article on “Anciens et modernes," in idem, Questions sur l'Encyclopédie, 1: 259.

124 Longinus, Traité du sublime, trans. Boileau, ed. Francis Goyet (Paris: Livre de poche, 1995), 150 (Paris: Thierry, 1674).
} 
flights that Virgil was not able to reach, and in the Old Testament we find several passages more elevated and sublime than any in Homer . . . In brief, says the abovementioned English author, we may be more exact than the ancients but we cannot be so sublime. ${ }^{125}$

According to this view, the farther one travels in time and space, the more likely one is to encounter sublime literature. Antiquity and the Orient are assimilated as sources of geniuses capable of sublimity. Dubos used the category of the sublime to "prove historically" that great authors like Virgil had created their own audiences, who were moved by the sublimity of what they read:

Besides, it is an easy matter to prove historically and by a deduction of facts that Virgil and the other excellent poets of antiquity are not indebted to colleges nor to early prejudices for their first admirers. This opinion cannot be maintained except by a person who does not carry his reflections beyond his own time and country. The first admirers or Virgil were his own countrymen and contemporaries. ${ }^{126}$

This "historical" argument was directed against the idea (advanced by the moderns) that the reputation of ancient authors was based on prejudice and unexamined authority. Dubos went further and claimed that Virgil had been appreciated by readers in different times and with different cultural backgrounds. ${ }^{127}$

Dubos was using the sublime as a transhistorical and transcultural category. For him, the power of genius was such that it compelled readers to acknowledge its sublimity always and everywhere. On the other hand, and somewhat contradictorily, Dubos argued that a historicist approach was necessary to appreciate the sublimity of ancient or Asian texts that might offend modern taste. In any case, Dubos's use of the sublime had one goal: retrieving the beauty of ancient texts in toto. A reader who was educated enough to appreciate the sublimity of the Iliad should be able to enjoy every single line in the poem.

Voltaire did accept some of Dubos's assumptions, but he put them to different use. For him, the sublimity of a passage was proof that it followed some "eternal laws, submitted to by all nations, because enacted by nature." 128 As a modern, Voltaire engaged in apodictic reasoning: the sublime was the manifestation of general laws that were inscribed in nature. Dubos reasoned "historically": he presented the public success of sublime works of literature as an empirical fact, without drawing consequences about human nature. Another subtle but essential difference is that while Dubos used the sublime to recover the original beauty of a work as a whole, Voltaire used the sublime in order to anthologize. In the

125 Dubos, Réflexions critiques, vol. 2, sect. 39, 566. The "English poet" is Addison (The Spectator, 3 Sept. 1711).

126 Dubos, Réflexions critiques, vol. 2, sect. 34, 499.

127 Ibid., sect. 34, 502.

128 Voltaire, An Essay on Epic Poetry, 308. 
passage above, Voltaire isolates one sublime line in Corneille, and characterizes the following lines as weak. Generally, his approach to all literature, ancient and modern, was to sort out the good and the bad, "the former being often next to the latter." 129 In French literary history, Voltaire is often criticized for his very narrow, neoclassical taste. Such criticism is understandable, but Voltaire's practice as a literary critic must be put in the context of his practice of universal history. As Meinecke puts it, he "divided the life of history into an enormous rubbish heap and a very small pile of precious metals." ${ }^{\prime 30}$ In literary history, this meant using a single standard of judgment across time and space in order to extract those few passages that were universally considered beautiful.

\section{CONCLUSION}

How does one account for Voltaire's presentism in a scenario that gives him a key role in the development of modern historical thought? As we saw in the introduction, the standard approach is to treat it as an embarrassing shortcoming and to focus on other aspects that are consistent with Rankean orthodoxy. However, it is not enough to say that academic history, especially in Germany, moved away from Voltaire's present-centered history, since important aspects of Voltaire's approach can still be seen in eighteenth- and even nineteenth-century German academic history. The historians of the Göttingen School criticized Voltaire for his sloppy use of sources, and because, as Momigliano puts it, he had abolished the footnote. ${ }^{131}$ Yet they implemented the essential aspects of Voltaire's program regarding universal history. Like Bossuet and Voltaire, Schlözer was interested in the allgemeiner Blick ${ }^{132}$ and he professed to study moeurs rather than kings and battles. Gatterer coined the term nexus rerum universalis to describe what the universal historian was looking for, and he spoke of the need to examine events as "systems" rather than "aggregates." 133 The discriminating attitude of the Göttingen historians was similar to Voltaire’s. As Escudier puts it, "universal

129 Voltaire, article on “Anciens et modernes," in idem, Questions sur l'Encyclopédie, 1: 259.

130 Meinecke, Historism, 89.

${ }^{131}$ Arnaldo Momigliano, "The Rise of Antiquarian Research," in idem, The Classical Foundations of Modern Historiography (Berkeley: University of California Press, 1990), 54-79.

132 August Ludwig Schlözer, Vorstellung seiner Universal-Historie, repr. with introduction and commentary by Horst Walter Blanke (Waltrop: Spenner, 1997), 18 (2 vols., Göttingen: Dieterich, 1772-3).

133 See Alexandre Escudier, "Theory and Methodology of History from Chladenius to Droysen: A Historiographical Essay," in C. R. Ligota and J.-L. Quantin, eds., History of Scholarship: A Selection of Papers from the Seminar on the History of Scholarship Held Annually at the Warburg Institute (Oxford: Oxford University Press, 2006), 437-85. 
history attends to some nations rather than others according to their importance in the transformations of the world. The unselected others rate no more than summary acknowledgement of their existence. . The rest is 'dross' [Schlacke]."134 In an 1862 essay Dilthey showed how Schlosser, the most successful historian in Germany before the triumph of Ranke's school, continued a tradition of universal history that went back to Schlözer (Schlosser's teacher in Göttingen) and, beyond Schlözer, to Voltaire's philosophical history. ${ }^{135}$ Schlosser himself was aware of this lineage. In his History of the Eighteenth Century, he credited Voltaire for having taught Schlözer and others after him how to be severe in judging the past:

One of the most accurate and industrious German "Instructors in History," Schlözer, therefore thankfully acknowledged how very much he and others like him, who had been accustomed to estimate external greatness alone, to call Miltiades a mere village bailiff when compared with Attila and Zinghis Khan, and Athens a little nest, must ever remain indebted to Voltaire: others of us are indebted to him. ${ }^{136}$

Schlosser admired Voltaire for "passing judgment upon every other age, in the sober discretion of his own." 137 The great names and places of antiquity had to endure the comparison, done without any indulgence, between the recent past and the distant past, as well as between the various regions of the world, far and near. It can be argued that Ranke still belongs in some ways to this tradition of a present-centered universal history. Granted, Ranke famously said that every age is next to God, but in the preface to his unfinished Universal History he wrote, in an anthologizing approach that is reminiscent of Voltaire's, about "a sort of heirloom" that "the human race has won for itself," including "those immortal works of genius in poetry and literature, in science and art." ${ }^{\prime 38}$ Like Voltaire, Ranke believed that universal history could not concern itself with the history of primitive peoples, and the ancient histories of India and China could not be included because they belonged to the realm of the fabulous. These matters could be studied but, as in Voltaire, they belonged in natural history. ${ }^{139}$ The more ethnocentric

$134 \quad$ Ibid., 458.

135 Wilhelm Dilthey, "Friedrich Christoph Schlosser and the Problem of Universal History," in idem, Hermeneutics and the Study of History, 307. This essay was originally published anonymously in 1862 in the Preussiche Jahrbücher.

${ }_{136}$ Friedrich Christoph Schlosser, History of the Eighteenth Century, and of the Nineteenth, till the Overthrow of the French Empire, with Particular Reference to Mental Cultivation and Progress, trans. D. Davison, vol. 1 (London: Chapman and Hall, 1843), 273 (Geschichte des achtzehnten Jahrhunderts in gedrängter Übersicht (Heidelberg: J. C. B. Mohr, 1823)).

137 Ibid.

${ }_{138}$ Leopold von Ranke, Universal History (New York: Scribner's, 1884), xiii (Weltgeschichte, 16 vols. (Leipzig: Duncker \& Humblot, 1881-8)).

139 See John A. Moses, "Ranke Revisited: The 'Dubious' Values of a Universal Historian," Journal of Religious History 14/2 (1986), 178. 
aspects of Ranke's position would be untenable today, but the basic division in the study of the past between history and prehistory is seldom questioned. Yet, as Hayden White has argued, it suggests that "there are two orders of humanity, one which is more human-because it is more historical — than the other." ${ }^{40}$

In his historically informed critique of nineteenth-century German historicism, Gadamer argues that "even the 'historical school' knew that fundamentally there can be no other history than universal history, because the unique significance of the detail can be determined only from the whole."141 In that sense, "the self-evident assumption of historical research is that history constitutes a unity."142 Gadamer stresses Ranke's "methodological naiveté" in dealing with the assumption of an uninterrupted continuity in the development of world history. He shows how Ranke marvels at the fact that "something unique finally emerges from the vast and multifarious whole of historical developmentnamely the unity of Western civilization which, produced by the Germanic and Romance peoples, spreads over the whole earth."143 Gadamer highlights an obvious fact that Ranke does not see: "That world history has produced Western culture in a continuous development is not a mere fact of experience that consciousness acknowledges but a condition of historical consciousness itself." 144 This must be noted even if one shares Ranke's sense of wonder. "Nor is it by chance," Gadamer continues, "that the unity of history depends on the unity of Western civilization, to which belong Western science in general and history as science, in particular." 145 According to Meinecke, the most important thing that Voltaire and nineteenth-century historians have in common is "the sovereignty of historical judgment." ${ }^{146}$ In Voltaire, this sovereignty is grounded in the values and preferences of the present. In Ranke, it is grounded in an implausible timelessness that hides an actual grounding in the pre-judgments of the present. In that sense, Voltaire has the merit of postulating explicitly what is an implicit assumption in Ranke, and seeing the hidden continuities between Voltaire and Ranke helps reveal some of the blind spots in modern historicism.

In 1932 Cassirer argued that "the common opinion that the eighteenth century was an 'unhistorical century,' is not, and cannot be, historically justified." $\mathrm{He}$

140 Hayden White, The Content of the Form: Narrative Discourse and Historical Representation (Baltimore: Johns Hopkins University Press, 1987), 55.

${ }^{141}$ Hans-Georg Gadamer, Truth and Method, translation revised by Joel Weinsheimer and Donald G. Marshall (New York: Crossroad, 1992), 200 (Wahrheit und Methode (Tübingen: J. C. B. Mohr, 1960)).

142 Ibid., 208.

143 Ibid.

144 Ibid.

145 Ibid., 209.

146 Meinecke, Historism, 63. 
added that "there is a strange irony in the fact that Romanticism, in the charge it brings against the Enlightenment in the name of history, makes the same mistake of which it accuses its opponent." 147 Yet the rehabilitation of eighteenth-century historicism by Cassirer (and Peter Gay after him) was predicated on the notion that Voltaire and his followers should be praised for their methodological advances but criticized for their naive presentism. What I have tried to show here is that there was nothing naive about Voltaire's presentism. Voltaire, as is apparent in his dialogue with Dubos, was deeply familiar with the humanist artes historicae, and he deliberately moved away from this tradition because he felt that the humanist "art of distancing" did not do justice to the claims of the present. As Hayden White has argued, to the extent that it is a deliberate choice, Voltaire's presentism is not a blind spot in his approach. ${ }^{148}$ The shortcoming (or blindness, or limitation, depending on the characterization one prefers) is paradoxically in what he is usually praised for: an absolute reliance on the distinction between fact and fiction for assessing historical truth (this would require another study, which I hope to conduct later). In that sense, Cassirer is quite right that modern historians have been insufficiently historical in their assessment of Voltaire. However, we must take his reappraisal of Voltaire one step further: Voltaire is a major figure in the history of historiography not in spite of his presentism (as Cassirer and Gay have argued), but because of it. And faulting Voltaire for his presentism is naive, because it overlooks the presentism that underlies the entire edifice of modern historicism.

One of the results of Gadamer's critique of nineteenth-century historicism (which appeared around the same time as E. H. Carr's lectures on history ${ }^{149}$ ) is a better awareness of the fact that historical scholarship itself is a product of history, and of the implications of this fact. What Gadamer calls for is a retrieving of the humanist understanding of the past that remains aware of the Enlightenment's critique of humanist history. He has shown, in his reappropriation of humanist hermeneutics (foreshadowed in Droysen's work), that the relationship between past and present need not be one-sided, and may take the form of a dialogue. ${ }^{150}$ The past has claims on the present, just as the present has claims on the past. Voltaire's contribution was to give voice to the claims of the present.

\footnotetext{
147 Cassirer, The Philosophy of the Enlightenment, 197.

148 Hayden White, "The Irrational and the Problem of Knowledge in the Enlightenment," in Harold E. Pagliaro, ed., Irrationalism in the Eighteenth Century (Cleveland: Press of Case Western Reserve University, 1972), 303-21.

149 Carr defines history as "an unending dialogue between the present and the past." E. H. Carr, What is History? 2nd edn (London: Macmillan, 1986; first published 1961), 24.

150 Gadamer, Truth and Method, 3-42 and 362-79.
} 